\title{
SANVITALIA SPECIOSA IN THE HORTICULTURAL TRADE: UNKNOWN ORIGIN, UNCERTAIN IDENTITY BUT NO SANVITALIA
}

\author{
J. Uher \\ Received: January 26, 2012
}

\begin{abstract}
UHER, J.: Sanvitalia speciosa in the horticultural trade: uknown origin, uncertain identity but no Sanvitalia. Acta univ. agric. et silvic. Mendel. Brun., 2012, LX, No. 6, pp. 339-342

Sanvitalia speciosa is a widespread but apparently invalid name used in the horticultural trade for a delicate plant of unknown origin which was introduced to cultivation nineteen years ago. A number of morphological characters on this is uncommon in the subtribe Zinniinae and suggest that the plant really belongs to the genus Melampodium. In the genus Melampodium, the cultivated plants obviously belongs to the section Rhizomaria, but their identity remain uncertain: the plants seem to be close to M. montanum BENTH. but a number of characters that are unusual in this species has been recorded.
\end{abstract}

Melampodium, Sanvitalia of gardens, varieties, taxonomy

The mesoamerican genus Sanvitalia LAM. comprises perennial and annual herbs that are characterised, along with other genera in the subtribe Zinniinae, by persistent and almost tubeless ray florets (KARIS and RYDING, 1994), but probably only five of the seven species accepted by TORRES (1964) form a monophyletic group. Especially Sanvitalia procumbens LAM. is well established under cultivation, and has been developed into varieties with deep purple disc florets and yellow, orange, or whitish ray florets. In the last few years, Sanvitalias have become economically important in the flower trade, being ranked 26th among the bedding plants at the Dutch flower auctions in 2004. Since then, turnover has dropped by 18 per cent to $€ 640,000$ in 2008 but this still represents sales of nearly 1.3 million plants. However, more than half of this amount is represented by a delicate plant with a number of rather small yellow heads, introduced nineteen years ago as Sanvitalia 'Aztekengold' (WICKI-FREIDL, 1993). Later, as a result of the registration of new cultivars, it was named $S$. speciosa, or S. hybrida (U.S. Plant Patents 14.140 P2, 14.799 P3, 15.210 P2, 15.881 P2, 15.954 P3, 17.869 $\mathrm{P} 2$, and $12.297 \mathrm{P} 2$, for example) in horticultural practice. However, the names S. speciosa and S. hybrida seem never to have been validly published and, furthermore, the plants in circulation conspicuously differ from other members of the genus Sanvitalia by the non-persistent ray florets, the dimorphic and biseriate involucral bracts in two rows, and the absence of a pappus - that are characters that suggest a rather close affinity to members of subtribe Melampodiinae (KARIS and RYDING, 1994). Some additional characters as the ray florets with the corolla attached on adaxial side of the ovary apex, and the inner bracts surrounding each ray-floret cypsela (a compound head with uniflorate female capitula? - as described by MANILAL, 1975) indicate that the plants actually belong to the neotropical genus Melampodium L. However, it proved to be difficult to decide what is the infrageneric position of plants being sold incorrectly under the name "Sanvitalia", as they set up some characters to combinations which are unusual in the particular taxonomic groups.

\section{MATERIAL AND METHODS}

The varieties 'Aztec Gold' (Ernst Benary Samenzucht GmbH), 'Sandeal' Cuzco Ideal, 'Santasol' Cuzco Trailing Yellow and 'Santanis' Cuzco Compact Yellow (Syngenta Seeds GmbH), 'Dittsun' Sunbini (Dittmar Hugo Samen \& 
Pflanzen), 'Wessacomp' Ariba, 'Wessastar' Sunny Star, and 'Wessateq' Tequilla (Westhof Vertriebs $\mathrm{GmbH})$, all available under the name Sanvitalia in the horticultural trade, were investigated, compared with herbarium specimens of the selected Melampodium taxa (see bellow) which can be commutable in their similarity, and discussed with relevant literature (STUESSY, 1972; STUESSY, 1979). Except to 'Aztec Gold' that is propagated by seed, all the others varieties were propagated by cuttings and, consequently, more uniform.

Specimens examined: NY 215027, M. mayfieldii TURNER, Belize: Cayo, MAYFIELD 1993; NY 215034, M. pilosum STUESSY, Mexico: Guerrero, HINTON 1937; NY 215026, M. longipilum ROB., Mexico: San Luis Potosí, PRINGLE 1893; NY 215035, M. sericeum LAG., Mexico: Jalisco, PALMER 1886; NY 215036, M. sericeum LAG., Mexico: Jalisco, PALMER 1886; NY 215029, M. montanum BENTH., Mexico: Chiapas, KING 1960 (var. viridulum isotype); DS 444246, M. americanum L., Mexico: Chiapas, KING 1960; DS 515541, M. montanum BENTH., Mexico: Chiapas, BREEDLOVE 1965; DS 584591, $M$. montanum BENTH., Mexico: Chiapas, LAUGHLIN 1966; DS 622625, M. montanum BENTH., Mexico: Chiapas, CLARKE 1967; DS 585861, M. sericeum LAG., Mexico: Chiapas, BREEDLOVE 1965; DS 645590, M. sericeum LAG., Mexico: Chiapas, BREEDLOVE 1974; MO 2010844, M. montanum BENTH., Mexico: Chiapas, GHIESBREGHT 1864; MO 2010712, $M$. aureum BRANDEG., Mexico: Puebla, PURPUS 1909 (isotype); MO 2010826, M. americanum L., Mexico: Jalisco, PALMER 1886; TEX 185206, M. montanum BENTH., Mexico: Chiapas, KING 1960 (var. viridulum isotype); F 1880113, M. microcephalum LESS., Mexico: Veracruz, ORTÍZ 1978; F 2120617, M. sericeum LAG., Mexico: Michoacan, ESCOBADO 1991; F 1759940, M. montanum BENTH., Guatemala: Huehuetenango, MOLINA 1971; GBH 12871, M. americanum L., Mexico: Michoacán, HINTON 1939; GBH 22144, M. montanum BENTH., Mexico: Nuevo León, HINTON 1992; GBH 22449, M. montanum BENTH., Mexico: Nuevo León, HINTON 1992; GBH 23089, M. montanum BENTH., Mexico: Nuevo León, HINTON 1993; GBH 23207, M. montanum BENTH., Mexico: Nuevo León, HINTON 1993; GBH 22908, M montanum BENTH., Mexico: Nuevo León, HINTON 1993; GBH 26677, M. montanum BENTH., Mexico: Oaxaca, HINTON 1996; GBH 27266, M. montanum BENTH., Mexico: Nuevo León, HINTON 1998; GBH 23449, M. montanum BENTH., Mexico: Nuevo León, HINTON 1993; GBH 24819, M. montanum BENTH. Mexico: Hidalgo, HINTON 1994; GBH 26032, $M$. montanum BENTH., Mexico: Oaxaca, HINTON 1995; GBH 26175, M. montanum BENTH., Mexico: Oaxaca, HINTON 1995; GBH 26388, M. montanum BENTH., Mexico: Oaxaca, HINTON 1995; GBH 26544, $M$. montanum BENTH., Mexico: Oaxaca HINTON 1996; GBH 26189, M. montanum BENTH., Mexico: Oaxaca, HINTON 1996.

\section{RESULTS AND DISCUSSION}

The names S. speciosa and S. hybrida seems never to have been validly published and, as has been mentioned above, the plants cultivated under this names are not sanvitalias but really belongs to the genus Melampodium. Among the 37 Melampodium species accepted by STUESSY (1972), only a compact strain of the widely spread neotropical weedy plant $M$. divaricatum (RICHARD) DC. is common in cultivation (usually as $M$. paludosum H.B.\& K.). However, this is a very distinct erect herb of the section Serratura STUESSY, with large and long petiolate leaves, heads that reach up to $30 \mathrm{~mm}$ in diameter and with outer involucral bracts connate to one third of their length.

The new Melampodium plants in cultivation were introduced to the horticultural trade by H. DITTMAR of Deitingen, Switzerland, but nothing more is known about their origin. They has become a very popular garden plants in the last decade and perhaps more than thirty cultivars have been registered, although they have all been distributed incorrectly under the name "Sanvitalia". They are slender, decumbent to ascending herbs which are apparently perennial, though they are typically cultivated as annuals propagated usually by cuttings (however, seeds are available on the market for the 'Aztekengold' and 'Million Suns' varieties). Their heads consist of 12-14 yellow, narrowly elliptic to almost linear rays, sometimes with purple veins beneath, and disc florets that are numerous (usually more than 60), yellow-green, with abortive ovaries. Ray cypselas are smooth and relatively small (approximately $1.5 \mathrm{~mm}$ long), without a hood. These characters seem to indicate that the "Sanvitalia" on sale is most closely allied to Melampodium montanum BENTH., a delicate species of the section Rhizomaria STUESSY. All varieties under observation approached to features of this species closely, showing some variances in the head size ( $12 \mathrm{~mm}$ or slightly more in 'Dittsun', 'Santanis' and 'Santasol' varieties, but to $20 \mathrm{~mm}$ in 'Wessastar'), the ray florets size and colour shade (Tab. II), the stem colour (RHS green 144B in 'Wessastar' to purple 187A-199C in 'Sandeal', 'Santasol', and 'Wessacomp'), the leaf size and colour (Tab. I), and the length of internodes and compactness - but there also seems to show some character combinations which are new to the genus Melampodium. The leaves on the wirelike stems are sessile, narrowly ovate to oblong, sparsely strigilose above but glabrous beneath. The outer involucre consists of five ovate, at the base only slightly connate bracts, glabrous on both surfaces, and with scarious margins. In contrast, $M$. montanum has somewhat villous stems and leaves strigose on both surfaces, the outer involucral bracts are connate for more than a fifth of their length and villous with hairs to $1 \mathrm{~mm}$ long on the abaxial surface. Melampodium aureum BRANDEG., the second species of the section Rhizomaria, is similar having the outer involucral bracts villous 
and connate for a fifth of their length, but its heads are significantly larger. Slightly connate bracts on the outer involucrum, glabrous on both surfaces, are characteristic of Melampodium glabribracteatum STUESSY (section Melampodium), but this species differs markedly by having small heads with 6-8 ray florets only, and no more than 30 yellow disk florets. The wire-like purple stems and outer involucral bracts that are only slightly connate resemble those of Melampodium americanum L. (section Melampodium) with its similar habit, but its phyllaries are characterized by herbaceous margins and strigose hairs near the apex, its leaves are sericeous beneath and occasionally lobed, the disc florets are yellow-orange with non-abortive ovaries, and the cypselas are considerably larger. In the mountain pine-oak forests of Oaxaca, in Mexico, their ranges overlap at elevations of $1800-2400 \mathrm{~m}$, where the very widespread $M$. americanum can be encountered with M. montanum. However, even though STUESSY (1979) regards the taxa of section Rhizomaria to be closely allied to section Melampodium, the molecular phylogenetic analysis employing both nuclear (ITS) and plastid (matK) DNA sequences (BLÖCH et al.,

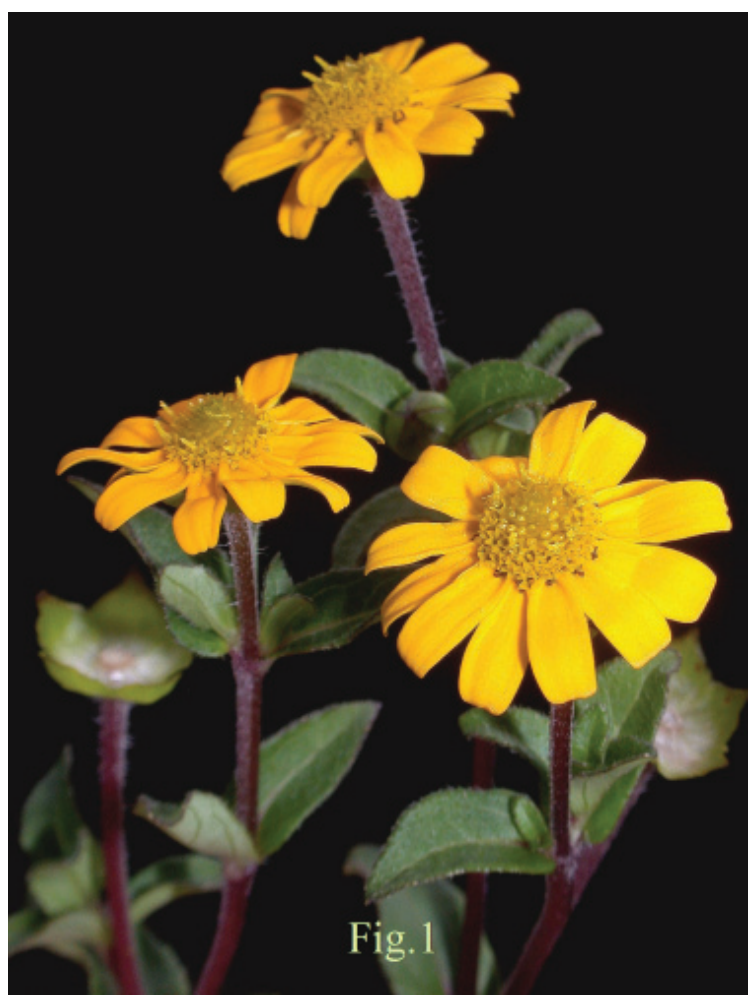

l: Melampodium (sect. Rhizomaria) 'Aztec Gold' ("Sanvitalia" of gardens)
2009) did not support such conclusions and natural hybridization seems to be rather improbable, as the taxa of both sections possess a different caryotype (TURNER and KING, 1962; STUESSY, 1971). Therefore, in all probability, the cultivated plants currently being sold as "Sanvitalia" are not of hybrid origin. Finally, they may well represent a somewhat anomalous strain of Melampodium montanum, as this species is exceptionally variable containing the populations of very different leaf shape (MO 2010844, F 1759940, GBH 22449, and GBH23449, for comparison of the most extreme genotypes - if each of these really belong to this species), clothing and growth pattern. There are populations that differ by possesing or lacking anthokyans (var. montanum versus var. viridulum). However, if the latter were recognized in the quality of distinct variety (STUESSY, 1972), then a query arise whether the unique features of involucral bracts, that are unusual for both of species ranked into the section Rhizomaria, can to justify a determination of new distinct taxon either at subspecific or specific level - to decide this, further investigations are necessary.

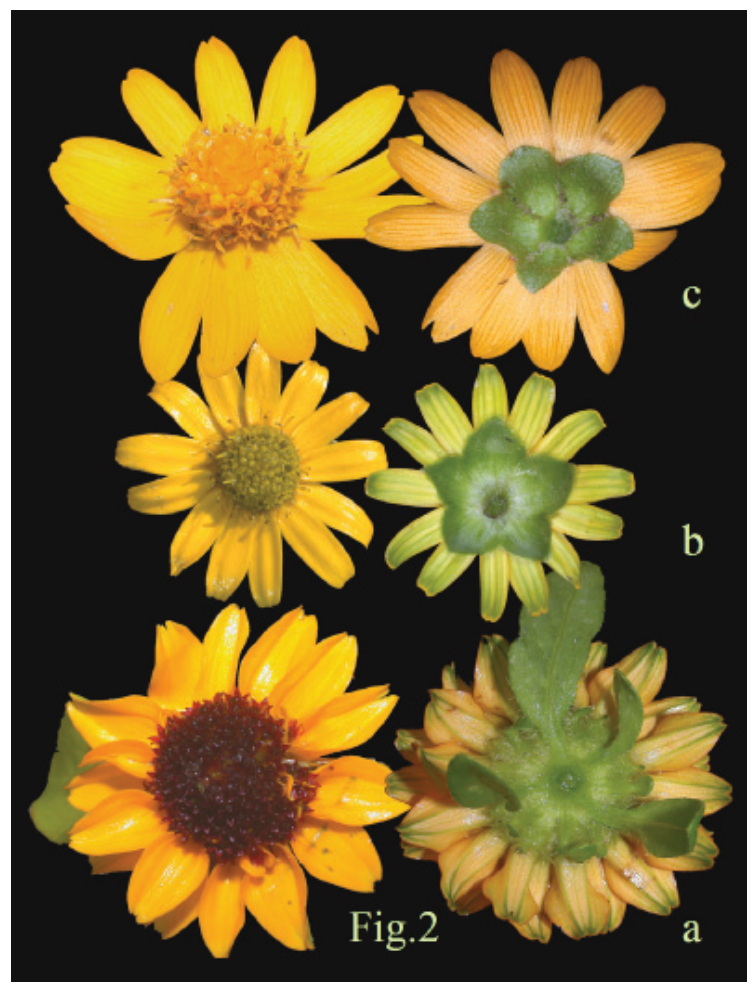

2: a) Sanvitalia procumbens 'Yellow Sprite'; b) Melampodium (sect. Rhizomaria) 'Aztec Gold'; c) Melampodium divaricatum 'Medaillon'

\section{SUMMARY}

Sanvitalia speciosa is undoubtedly invalid but currently used name for a delicate perennial plant of unknown origin in the horticultural trade, introduced to cultivation nineteen years ago. However, it is cultivated as annual and analogously to the sanvitalias, that plants are developing a number of little yellow heads untiringly - a number of morphological traits such as the dimorphic involucral 
bracts in two rows (of whom, the bracts in the inner row are surrounding each ray-floret cypsella), the ray florets that are dorsally attached to the ovary apex, and the homomorphic cypsella without a pappus, are rather uncommon in the subtribe Zinniinae and suggest that the plant really belongs to the genus Melampodium. In the genus Melampodium, the cultivated plants undoubtedly belongs to the section Rhizomaria, but their identity remain uncertain. Apparently, the plants seem to be close to M. montanum BENTH. but a number of characters that are unusual in this species has been recorded. However, as the M. montanum specimens under observation seems to be exceptionally variable containing the populations of very different leaf shape, clothing and growth pattern, a study of their characters dissimilarities needs further observations before the conclusion if the plants under cultivation include to M. montanum, or if emplacement the new taxon would be preferable.

\section{Acknowledgment}

I would like to thank to Tod F. Stuessy (W) for manuscript review, his critical comments and providing the additional information. Thanks also to Malcolm Russell for English grammar corrections and suggestions. I am also grateful to curators of the MO, NY, DS, TEX and F herbaria for making their collections available for study.

\section{REFERENCES}

BLÖCH, C., WEISS-SCHNEEWEISS, H., WEISSSCHNEEWEISS, G. M., BARFUSS, M. H. J., REBERNIG, C. A., VILLASEÑOR, J. L., STUESSY, T. F., 2009: Molecular phylogenetic analyses of nuclear and plastid DNA sequences support dysploid and polyploid chromosome number changes and reticulate evolution in the diversification of Melampodium (Millerieae, Asteraceae). Mol. Phylogenet. Evol. 53 (1): 220233.

KARIS, P. O., RYDING, O., 1994: Tribe Heliantheae. In: BREMER K. (ed.): Asteraceae cladistics \& classification. Timber Press, Portland, Oregon: 559-624.

MANILAL, K. S., 1975: A compound capitulum of Melampodium. Bot. J. Linn. Soc. 70 (1): 71-75.
STUESSY, T. F., 1971: Chromosome numbers and phylogeny in Melampodium (Compositae). Am. J. Bot. 58 (8): 732-736.

STUESSY, T. F., 1972: Revision of the genus Melampodium (Compositae-Heliantheae). Rhodora 74 (1): 1-70, and (2): 169-219.

STUESSY, T. F., 1979: Cladistics of Melampodium (Compositae). Taxon 28 (1, 2/3) 179-195.

TORRES, A. M., 1964: Revision of Sanvitalia (Compositae-Heliantheae). Brittonia 16 (3): 417433.

TURNER, B. L., KING, R. M., 1962: A cytotaxonomic survey of Melampodium (Compositae-Heliantheae). Am. J. Bot. 49 (3): 263-269.

WICKI-FREIDL, P., 1993: 'Aztekengold' für Beet und Balkon: eine neue Sanvitalia-Sorte mit besondere Eigenschaften. Der Gartenbau 114 (1): 24-25. 